\title{
Developing a Model of Compulsory Basic Education Completion acceleration in Support of Millennium Development Goals in Magelang, Indonesia
}

\author{
Sukarno $^{1} \&$ Sri Haryati ${ }^{1}$ \\ ${ }^{1}$ Faculty of Education and Teacher Training, Tidar University, Indonesia \\ Correspondence: Sukarno, Faculty of Education and Teacher Training, Tidar University, Jl. Kapten Suparman 39 \\ Magelang, Indonesia. Tel: 293-361-497/81-325-877-915. E-mail: sukarno_edc@yahoo.co.id
}

Received: March 24, 2015 Accepted: May 6, 2015 Online Published: June 29, 2015

doi:10.5539/ies.v8n7p127 URL: http://dx.doi.org/10.5539/ies.v8n7p127

\begin{abstract}
This article reports Year One of a two-year study to develop a model to accelerate compulsory basic education completiontoward Millennium Development Goals (MDGs) in Magelang, Indonesia. The study focuses on five issues: (1) profile of MDGs in Magelang, (2) achievement of MDGs, (3) problems in MDGs implementation, (4) model of compulsary basic education completion acceleration, and (5) effectiveness of the model proposed. As R\&D undertaking, the data were collected through documentation and interviews with related authorities, including focused group discussion. The initial model underwent a limited test for necessary revision. The findings showed that the Local Government has implemented the compulsary education with relatively high gross and net enrolment rates of $96.80 \%$ and low dropouts and repeaters rates. In 2013-2014, many of the students were from outside Magelang. However, such achievements have not complied with MDGs. One possible cause of the problems was a top-down management system, resulting in low participation of the society members. In conclusion, Magelang Municipality has actually been highly committed to the completion of basic education in accordance with the strategic plans 2010-2014 of the National Education Ministry. A team was established to organize relevant activities to accelerate full implementation of the program. Recommended in Year One of the study were that (1) the Local Government's commitment to education be sustained, (2) the society members' participation be optimized in data inventories, planning, implementation, monitoring and evaluation of the program, and (3) the optimization of the society's participation be supported by Local Government, including the stakeholders.
\end{abstract}

Keywords: compulsorybasic education, MDGs, enrolment rate, acceleration model

\section{Introduction}

\subsection{Background}

As agreed upon by 189 heads of states as members of UNO, Millennium Development Goals (MDGs) include eight issues, namely (1) to alleviate poverty and hunger, (2) to achieve basic education for all (achievement of general primary education), (3) to enforce gender equality and woman empowerment, (4) to lower infant death rates, (5) to improve maternal health, (6) to fight against HIV and Malaria, (7) to conserve natural environment, and (8) to enforce global relationship for development. These seven goals were supposed to be achieved in 2015 (Bappenas, 2010).

Of the eight MDGs, dealt with in the current study was Goal 2, to achieve basic education for all in which four indicators were used, namely Gross Enrolment Rate (APK), Net Enrolment Rate (APM), Dropout Rate (APS), and Repeaters Rate (AM). In this respect, in 2015 all citizens aged ranging from seven to sixteen years were supposed to complete the compulsary basic education without regard to where they were within the Indonesian archipelago. For this, much had been undertaken by Local Authorities throughout Indonesia as stipulated in Law No. 22/1999, and revised in Law No. 32/2004 in which Local Authorities in the spirit of education decentralization were responsible for implementation of basic education. Besides, it was also stipulated in Indonesian Constitution 1945, Article 31 that the implementation of basic education becomes the Government's responsibility, regulating that the education budget is $20 \%$ of the national budget. The commitment to implementation of basic education was further stipulated in Law No. 20/2003, on National Education System, 
namely in Articles 17 and 34 (Bappenas, 2013). Furthermore, the Government also issued a new policy called 'BOS' (School Operational Grant) to help eradicate possible student drop-outs. This grant had been given to State Schools (ES, HS) and some private schools. Despite the pros and cons of the grant, it really helped solve some of the school problems.

Previous studies by Bappenas (Ministry of National Development Planning) indicated the success of basic education program implementation as reflected in literacy education, and thus was classified as 'being on track' toward MDGs 2015. It was even reported as going beyond the target, and therefore Junior High School was made the target of universal basic education. In 2008-2009, the gross enrolment rate of Elementary and Junior high, including Learning Package A was of 116.77 percent and net enrolment rate (APM) of 95.23 percent. Meanwhile cross-provincial net enrolment rate was of 90 percent. In acceleration of achievement, one challenge was identified as having to provide equal chances of access to quality education for the children across the nation. The Government had taken some steps in response to the problem, namely by (1) providing a wider access to quality education, especially for the poor, (2) improving quality and relevance to educational services, and (3) improving management of educational services across the archipelago.

In practice, by Education Office in each Local Authority, the implementation of the compulsory education program is organized, monitored and evaluated to see how it goes. And to facilitate the process, several strategic policies have also been devised, such as upgrading the infrastructure, opening up opportunities for teachers to pursue further education, and improving the educational services, by providing easy access to school hot spots (internet access) for the students and teachers alike to get information. Libraries have also been digitally updated to facilitate information retrieval.

With respect to Magelang Municipality, the local goverment has also struggled very hard in providing educational facilities as a global commitment to improving educational endeavors, especially through a medium-term development plan 2010-2015. The plan has been broken down into annual operational plans and actions. However, according to the recent monitoring and evaluation, the target of MDGs in educational field has not been achieved yet. It is indicated by the gross and net participation indexes which are only $96,80 \%$ for Elementary Schools and 95,65\% for High Schools (Monitoring Team, 2014). Basically, there are currently three issues of compulsary education implementation, namely (1)there are children of basic education age, who do not received sufficient education access, especially the 'street' children and children with disabilities, (2) there are not enough Elementary and High School teachers in addition to (3) lack of competent teachers.

The current study (R\&D) was therefore aimed at developing a model to accelerate the achievement of fully-implemented compulsary education in Magelang Municipality as a commitment to support the target as set in Millennium Development Goals 2015.

\subsection{Statement of the Problems}

Based on the background, the research questions can be formulated as (1) 'What model can be employed to accelerate the completion of the compulsary basic education program in Magelang?' and (2) 'To what extent is the model effective?'

In this respect, a model has to be devised and its effectiveness tested in order to come up with a rigid model which can be used in different educational contexts throughout at least Central Java as the target of completion is of 2015. The steps employed in devising the model included (1) Exploration Phase in which the program implementation was investigated; the results and problems of implementation identified, (2) Model Development Phase in which the model was designed, and (3) Model Evaluation in which the model was tested in a narrow scope to find out its effectiveness.

\section{Method}

\subsection{Approach to the Stud}

The current study is Research and Development (R\&D) in nature. As outlined in Borg and Gall (2007), R\&D is a process of investigation employed to develop and validate or test a product (of education). To accomplish the study, the researchers have, therefore, to conduct a needs analysis on which to design the product, and to test its effectiveness so as to be used for a more general scope (Sugiyono, 2009).

In the current $\mathrm{R} \& \mathrm{D}$, the product developed and validated to accelerate the completion of the achievement of MDGs in education sector consists of (1) description of achievement of MDGs in Magelang, (2) a guide book to acceleration of achievement completion of MDGs in Magelang, and (3) a report of validation of the model to accelerate the completion of MDGs in Magelang. 


\subsection{Data Collection}

The techniques of data collection are interviews, document studies and focused group discussion (FGD). The three techniques are collaborative in nature in order to obtain the valid data. Interviews were used to obtain the data on the current achievement of MDGs. Meanwhile, FGD (practitioner and expert judgments) was used to provide inputs for the current model.

\subsection{Research Procedures}

Modified from Borg \& Gall (2007)'s ten phases, the current study was performed in seven phases, namely (1) research and information collecting, (2) developing a preliminary form of product, (3) preliminary field testing, (4) main product revision, (5) main field testing, (6) final product revision, and (7) dissemination and implementation. As a two-year research project, Year One was limited to the first four phases, ending in the main product revision.

In research and information collection, the data were collected through field observation, document investigation, library research, and interviews with education authorities. In this preliminary phase, indicators of success of program implementation were identified, such as gross enrolment rate (APK), net enrolment rate (APM), drop-out rate (APtS) and repeaters rate (AU). Such indicators were used to justify whether or not certain schools have achieved mastery learning in the basic education. Meanwhile, in phase 2 (developing a preliminary form of product), a prototype of the proposed model was made, namely by (1) strengthening the institutions related to the implementation of basic education program, (2) integrating the targets of achievement indicators as prioritized program as the basis of fiscal and budgeting policies, (3) identifying the sub-target as under priority, (4) solving the possible problems that might have caused low achievement of mastery learning.

In preliminary field testing, the proposed model was launched to 'market'. In this case it was tried out in Magelang educational practice through the authority. Upon completion of the model trial, revision was performed to comply with demands from the field. This was done by focused group discussion (FGD) on considering the comments from related experts.

\section{Results}

\subsection{Basic Education Program Implementation}

Basically, the compulsary basic education in Magelang has been considerably well implemented. The Local Authority has formed a team of coordinators integrated in a program called 'education for all'. Listed below are various programs aimed at accelerating the basic education program toward the target of MDGs in 2015:

1) More assistance has been given to both state and private schools in infrastructure upgrading, new classrooms, textbooks, training for both administrative and teaching staffs to more develop their competencies.

2) Open Junior High School with respect to quality has been further empowered as a sustainable effort toward betterment of educational services.

3) Learning Packages A and B have been improved and made available for those who cannot join the formal school or drop out of schools or fail in the national exams. This includes trainings for special tutors.

4) Implementation of basic education has been optimized through religion-based boarding schools by adding three more subjects, namely, Indonesian language, mathematics and physics.

5) Small classes with private teachers have also been provided for better educational services.

6) The curriculum for basic education has also been improved, focusing on the achievement of minimum basic skills, employing the concept of mastery learning, and encouraging independent and critical attitudes in order to develop better system of values.

7) Soft skills for living have also been offered in basic education in order for the students to survive successfully in any discursive practice in the society.

8) Management trainings have also been conducted to improve the school management. Such trainings were mostly participated in by school principals, vice principals, and selected teachers.

9) A guide to school operation has also been issued by the Local Authority, such as community-based infrastructure, school budgeting, purchase of textbooks, quality control and teacher certification, and finally minimal service standard. 


\subsection{Achievements of MDGs in Education}

The Local Authority of Magelang has targeted the net enrolment rate (APM) of more or less $100 \%$ for Elementary Schools (SD), and the gross enrollment rate (APK) of $175.30 \%$ for High Schools (MI, SMP, MTS), resulting in decrease of dropouts and repeats of Elementary Schools in 2011, and of Junior High Schools in 2012. Revealed below are the data of compulsary basic education program implementation in Magelang.

Table 1. Total of basic education institutions in 2013-2014

\begin{tabular}{lllllllllll}
\hline \multirow{2}{*}{ No } & \multirow{2}{*}{ Sub-district } & \multicolumn{3}{l}{$2012 / 2013$} & \multicolumn{5}{c}{$2013 / 2014$} \\
\cline { 3 - 10 } & & SD & MI & SMP & MTS & SD & MI & SMP & MTS \\
\hline 1 & North Magelang & 22 & 1 & 7 & 1 & 23 & 1 & 7 & 1 \\
2 & Central Magelang & 32 & 0 & 8 & 1 & 32 & 0 & 8 & 1 \\
3 & South Magelang & 22 & 1 & 5 & 0 & 22 & 1 & 5 & 0 \\
& Jumlah & 76 & 2 & 20 & 2 & 77 & 2 & 20 & 2 \\
\hline
\end{tabular}

Source: Education Office (2014).

According to Table 3.1,in North Magelang one Elementary School (SD) was established, totaling 23 in 2013 / 2014 (23) as compared to 22 in 2012 /2013. Other institutions (Junior High Schools) remained the same. Central and South Magelang did not undergo any change in the number of schools in the period of 2011/2013 and 2013/2014. In conclusion, the number of schools in Magelang Municipality, relatively remain the same.

Table 2. Number of basic education students in 2013/2014

\begin{tabular}{|c|c|c|c|c|c|c|c|c|c|c|c|}
\hline \multirow{3}{*}{ No } & \multirow{3}{*}{ Sub-District } & \multicolumn{4}{|c|}{2013} & \multirow{3}{*}{ Total } & \multicolumn{4}{|c|}{2014} & \multirow{3}{*}{ Total } \\
\hline & & \multicolumn{2}{|c|}{ SD/MI } & \multicolumn{2}{|c|}{ SMP/MTS } & & \multicolumn{2}{|c|}{$\mathrm{SD} / \mathrm{MI}$} & \multicolumn{2}{|c|}{ SMP/MTS } & \\
\hline & & M & $\mathrm{F}$ & $\mathrm{M}$ & $\mathrm{F}$ & & $\mathrm{M}$ & $\mathrm{F}$ & $\mathrm{M}$ & FP & \\
\hline 1 & North Magelang & 2460 & 2274 & 2288 & 2335 & 9014 & 2292 & 2161 & 2270 & 2343 & 9066 \\
\hline 2 & Central Magelang & 3351 & 3191 & 2016 & 2165 & 10723 & 3181 & 3183 & 1778 & 1865 & 10007 \\
\hline \multirow[t]{2}{*}{3} & South Magelang & 2297 & 2094 & 749 & 783 & 6.266 & 2317 & 2125 & 920 & 927 & 6289 \\
\hline & Total & 8108 & 7559 & 5053 & 5283 & 26003 & 7790 & 7469 & 4968 & 5135 & 25362 \\
\hline
\end{tabular}

The table above shows that the number of students in Elementary Education (SD/MI) and High School (SMP/MTs) in the Sub-District of North Magelang, increased in 2013, that was from 9066 students to 9014 in 2014. In South Magelang District, the number of students of basic education in 2013 was of 6266 increasing up to 6289 students in 2014.This was due to fact that the primary school in North Magelang has become a favorite school or a primary option for parents. While in the Middle District of Magelang, a decrease was identified in the number of students of primary education, in 2013 which was 10,723 students, decreasing to 10007 students in 2014. This was probably due to the success of family planning program (birth control).

Another fact was that there were a number of Elementary Schools (SD/MI) which could not survive due to lack of students. The schools were then converted to Junior High School (SMP/MTs).

Table 3 below shows the net and gross enrolment rates for Elementary and Junior High Schools, including Learning Package A (specially designed for those cannot join the formal schools or they fail in the national examination. 
Table 3. APM \& APK at SD/MI/Package A 2012/2013 and 2013/2014-Magelang City

\begin{tabular}{|c|c|c|c|c|c|}
\hline \multirow{3}{*}{ No } & \multirow{3}{*}{ Sub-District } & \multirow{2}{*}{\multicolumn{2}{|c|}{$\begin{array}{c}\text { APM }(\%) \\
\text { Net Enrolment Rate }\end{array}$}} & \multirow{2}{*}{\multicolumn{2}{|c|}{$\begin{array}{c}\text { APK (\%) } \\
\text { Gross Enrolment Rate }\end{array}$}} \\
\hline & & & & & \\
\hline & & $2012 / 2013$ & $2013 / 2014$ & $2012 / 2013$ & $2013 / 2014$ \\
\hline 1 & North Magelang & 82.11 & 102.53 & 90,37 & 120.12 \\
\hline 2 & Central Magelang & 117.84 & 104.23 & 128,90 & 154.21 \\
\hline \multirow[t]{2}{*}{3} & South Magelang & 87.70 & 137.88 & 88,79 & 11420 \\
\hline & Magelang City & 96.81 & 114.87 & 107,05 & 129.53 \\
\hline
\end{tabular}

Source: BPS, Magelang City (2014).

Based on the above table, it can be explained that the achievement of APM for SD/MI/Package A in North Magelang in 2013/2014 amounted to 102.53 an increase of 20.42\% compared with the year 2012/2013 with only 82.11. Achievement of APM for SD/MI/Package A in Central Magelang in 2012/2013was of 117.84, a decrease of $13.61 \%$ in the year 2013/2014 which was only 104.23. In South Magelang in 2012/2013, the achievements of APMSD/MI/Package were 87.70, compared with the year 2013/2014, which was 137.88 , a decrease of 50.18\%.

The decreases in the three districts were due to the fact that the students who were identified were the ones only from Magelang alone, excluding those from outside the city of Magelang. When compared with the provincial rate of APM, which was 97.08, Magelangwas still under the provincial level because it only reached $94.21 \%$.

From the above data, it is clear that the achievement of APK in North Magelang District in the year 2012/2013 was $90.37 \%$, and when compared to the year $2013 / 2014$ reaching $120.12 \%$, there was an increase of $20.75 \%$. In Central Magelang District, the achievement of APK for SD/MI/Package A in the year 2012/2013 was 128.90\% when compared to the year $2012 / 2013$, reaching $154.21 \%$, there was an increase of $25.31 \%$. In South Magelang Sub-District, the achievement of APK for SD/MI/Package A in the year 2012/2013was $88.79 \%$ when compared to the year $2013 / 2014$, reaching $114.20 \%$, there was an increase of $19.88 \%$.

In the three districts, there were decreases due to the fact that the students were calculated on the basis of those from Magelang alone, excluding the students coming from outside the city of Magelang. When compared with the Province achievement of APK (119.02\%), Magelang (107.05\%) was then still under the Province level of achievement.

Tabel 4. Achievements of APM and APK SMP/MTs/Package B 2012/2013 and 2013/2014-Magelang City

\begin{tabular}{|c|c|c|c|c|c|}
\hline \multirow{3}{*}{ No } & \multirow{3}{*}{ Sub-District } & \multicolumn{2}{|c|}{ APM (\%) } & \multicolumn{2}{|c|}{ APK (\%) } \\
\hline & & \multicolumn{2}{|c|}{ Net Enrolment Rate } & \multicolumn{2}{|c|}{ Gross Enrolment Rate } \\
\hline & & $2012 / 2013$ & $2013 / 2014$ & $2012 / 2013$ & $2013 / 2014$ \\
\hline 1 & North Magelang & 106.08 & 102.67 & 133.06 & 148.64 \\
\hline 2 & Central Magelang & 83.38 & 107.93 & 107.31 & 150.48 \\
\hline 3 & South Magelang & 36.82 & 142.71 & 46.26 & 178.58 \\
\hline & Magelang City & 75.42 & 117.77 & 95.65 & 159.23 \\
\hline
\end{tabular}

Source: BPS of Magelang (2014).

The table above shows that the achievement of APM for SMP/MTs/Package B in North Magelang District in the year 2012/2013 was 106.08\%. When compared with the achievement of the APMSMP/MTs/Package B in North Magelang district, in the year 2013/2014 (102.67\%), there was a decrease of 3.41\%.

In Central Magelang District in 2012/2013, the achievement of APM for SMP/MTs/Package B was 83.38\%. When compared with the achievements of the APMSMP/MTs/Package B in 2013/2014 (107.93\%), there was an increase of 24.55. In South Magelang District in 2012/2013, the achievement of APM for SMP/MTs/Package B was $36.82 \%$. When compared with the achievements of the APMSMP/MTs/Package B in the year 2013/2014 amounted to $(142.71 \%)$, there was an increase of $105.53 \%$. When compared with the provincial level of 
APM75.87\% and at national level $75.64 \%$, Magelang is already above the provincial and national levels because it has already reached $117.77 \%$.

The above data describe the conditions of APK achievement in North Magelang District. Achievement of APK for SMP/MTs/Package B in North Magelang District in 2012/2013 was $133.06 \%$. When compared to the achievements of APK for SMP/MT/Package B in 2013/2014 which was $148.64 \%$, there was an increase of $15.58 \%$.

From the above data, it is clear that the achievement of APK in North Magelang District in 2012/2013 was $90.37 \%$. When compared with the year 2013/2014 which reached $120.12 \%$, there was an increase of $20.75 \%$. In Central Magelang District, the achievement of APK for SD/MI/Package A in 2012/2013 was $128.90 \%$. When compared with the year $2013 / 2014$, which reached $154.21 \%$, there was an increase of $25.31 \%$. In South Magelang District, the achievement of APK for SD/MI/Package A in the year 2012/2013 was $88.79 \%$. When compared with the year 2013/2014, which reached $114.20 \%$, there was an increase of $19.88 \%$.

In the three districts, there were decreases due to the calculation of the students, taking into account only those from Magelang alone, not including those outside Magelang City. When compared with the Province level of APK (119.02\%), the APK achievement in Magelang (107.05\%) was still under the Province level.

Table 5. Achievement of APM and APK for SMP/MTs/Package B 2012/2013 and 2013/2014-Kota Magelang

APM (\%) APK $(\%)$

\begin{tabular}{llcccc} 
No & District & \multicolumn{2}{c}{$($ Net Enrolment Rate $)$} & \multicolumn{2}{c}{ (Gross Enrolment Rate) } \\
\cline { 3 - 6 } & & $2012 / 2013$ & $2013 / 2014$ & $2012 / 2013$ & $2013 / 2014$ \\
\hline 1 & North Magelang & 106.08 & 102.67 & 133.06 & 148.64 \\
2 & Central Magelang 1 & 83.38 & 107.93 & 107.31 & 150.48 \\
3 & South Magelang & 36.82 & 142.71 & 46.26 & 178.58 \\
\hline & Magelang City & 75.42 & 117.77 & 95.65 & 159.23 \\
\hline
\end{tabular}

Source: BPS Magelang City (2014).

Table 5 above shows that the achievement of APM for SMP/MTs/Package B in North Magelang District the in the year 2012/2013 was $106.08 \%$. When compared with the achievement of the APM for SMP/MTs/Package B in North Magelang District in 2013/2014 which reached 102.67\%, it experienced a decrease of $3.41 \%$.

In Central Magelang District in 2012/2013, the achievement of APM for SMP/MTs/Package B was 83.38\%. When compared to the achievement of the APM for SMP/MTs/Package B in 2013/2014 which reached 107.93\%, there was an increase of 24.55. In South Magelang District in 2012/2013, the achievement of APM for SMP/MTs/Package B was $36.82 \%$, when compared with the achievements of APM for SMP/MTs/Package B in $2013 / 2014$ which reached $142.71 \%$, there was an increase of $105.53 \%$. When compared to the provincial level of APM (75.87\%) and APM at national level (75.64\%), Magelang was already above the provincial and national levels because Magelang had already reached $117.77 \%$.

The above data shows the condition of APK achievement in North Magelang District. For the achievement of APK for SMP/MTs/Package B in North Magelang District in 2012/2013 it was 133.06\%. When compared with the achievement of APK for SMP/MT/Package B in 2013/2014 which reached 148.64\%, there was an increase of $15.58 \%$.

In Central Magelang Sub-District, the achievement of APK for SMP/MTs/Package B in 2012/2013 was 107.31\%. When compared with the achievement of APK for SMP/ MT/Package B in the year 2013/2014 which reached $150.48 \%$, there was an increase of $43.17 \%$.

In South Magelang District, the achievement of APK for SMP/MTs/Package B in 2012/2013 was of 46.26\%. When compared with the achievements of APK for SMP/ MT/Package B in 2013/2014 which reached 178.58\%, there was an increase of $132.32 \%$. When matched with the Provincial level of APK (99.40\%), and national level (98.2\%), the APK for Magelang (159.23\%) was still above both provincial and national levels. This was because the number of the students was calculated on the basis of those from Magelang, namely excluding those from outside Magelang. 
Table 6. Rates of up-movers, dropouts, and repeaters for SD/MI 2012/2013 and 2013/2014 Magelang City

\begin{tabular}{llcccccc}
\hline \multirow{2}{*}{ No } & \multirow{2}{*}{ District } & \multicolumn{3}{c}{$2012 / 2013(\%)$} & \multicolumn{3}{c}{$2013 / 2014(\%)$} \\
\cline { 3 - 8 } & & Up-Movers & Dropouts & Repeaters & Up-Movers & Dropouts & Repeaters \\
\hline 1 & North Magelang & 97.01 & 0 & 2.99 & 98.92 & 001 & 2.41 \\
2 & Central Magelang & 97.20 & 0.04 & 2.80 & 97.46 & 0.02 & 1.93 \\
3 & South Magelang & 96.94 & 0.02 & 3.06 & 94.56 & 0 & 1.68 \\
\hline & Magelang City & 97.94 & 0.02 & 2.06 & 96.98 & 0.01 & 3.01 \\
\hline
\end{tabular}

Source: Education Office Data (2014).

Based on the above data, it is clear that students who move up a level of SD/MI in North Magelang District in 2012/2013 reached $97.01 \%$. When compared with the year 2013/2014 which reached $98.92 \%$, there was an increase of $1.91 \%$. Dropouts in North Magelang District did not exist, while repeaters underwent a decrease from 2.99 in 2012-2013down to 2.41 in 2013/2014, implying a decrease of $0.58 \%$.

In Central Magelang Sub-District, students who moved up a level in 2011/2012 reached 97.38\%. When compared to the year 2012/2013, which reached $97.20 \%$, there was a decrease of $0.18 \%$. Meanwhile, dropouts in Central Magelang District in 2011/2012 reached 0.08. When compared to the year 2012/2013 which reached 0.04, there was a decreaseof 0.04 , furthermore, in $2011 / 2012$, repeaters were $2.62 \%$, in $2012 / 2013$ they rose up to $2.80 \%$. This means there was an increase of $0.18 \%$.

In South Magelang Sub-District, students who moved up a level in 2011/2012 reached 95.94\%. When compared with the year 2012/2013, which reached $96.94 \%$, there was an increase of $1.00 \%$. Dropouts in South Magelang District in the year 2011/2012 reached $0.02 \%$, when compared with the year 2012/2013 which reached $0.02 \%$, it remained the same at $0.02 \%$, while repeaters in 2011/2012 reached $4.06 \%$; and $3.06 \%$ in 2012/2013. It means there was a decrease by $1.00 \%$. The above description shows that in Magelang there were dropouts or repeaters of SD students though the rate was relatively low.

Table 7. Rates of up-movers, dropout, and repeaters for SMP/MTS 2012/2013 and 2013/2014 Magelang City

\begin{tabular}{llcccccc}
\hline \multirow{2}{*}{ No } & \multirow{2}{*}{ District } & \multicolumn{3}{c}{$2012 / 2013(\%)$} & \multicolumn{3}{c}{$2013 / 2014(\%)$} \\
\cline { 3 - 8 } & & Up-Movers & Dropouts & Repeaters & Up-Movers & Dropouts & Repeaters \\
\hline 1 & North Magelang & 98.70 & 0.45 & 1.30 & 99.77 & 0.1 & 0.73 \\
2 & Central Magelang & 99.50 & 0 & 0.45 & 99.89 & 0.12 & 0.84 \\
3 & South Magelang & 98.75 & 0.30 & 1.25 & 99.68 & 0.08 & 0.79 \\
\hline & Magelang City & 98.75 & 0.25 & 1.00 & 99.78 & 0.10 & 0.79
\end{tabular}

Source: Education Office Data, Magelang (2014).

The above data show that students who moved up a level of SMP/MTs in North Magelang District in 2011/2012 reached $95.52 \%$. When compared with the year $2012 / 2013$, which reached $98.70 \%$, there was an increase of $3.18 \%$. Dropouts in North Magelang Sub-District in the year 2011/2012, who hadreached0.04, raised up to $0.45 \%$ in $2012 / 2013$ This means that there was an increase of $0.41 \%$. Meanwhile, repeaters in North Magelang District in $2011 / 2012$, who had reached $4.48 \%$, dropped down to $1.30 \%$ in the year $2012 / 2013$. This means that there was a decrease of $3.18 \%$.

In Central Magelang Sub-District, the students who move up a level in 2011/2012 reached $98.54 \%$. When compared to the year $2012 / 2013$, which reached $99.50 \%$, there was an increase of $0.96 \%$. Meanwhile, dropouts in Central Magelang Sub-District in 2011/2012 reached 0.29\%. When compared with the year 2012/2013 which reached $0 \%$, this means that in the Central Sub-District of Magelang there were no dropouts. As for the repeaters, in $2011 / 2012$, they reached $1.46 \%$ in $2012 / 2013$ but down to $0.45 \%$. This means there was a decrease of $1.01 \%$.

In South Magelang Sub-District, the students who move up a level in 2011/2012 reached $96.11 \%$. When compared to the year $2012 / 2013$, which reached $98.75 \%$, there was an increase of 2.64 . Meanwhile, dropouts in South Magelang District in 2011/2012 reached 0.31\%. When compared with the year 2012/2013 which reached 
$0.30 \%$, it means that there was a decrease in the dropout rate of $0.01 \%$, while the repeaters who had reached $3.89 \%$ in the year 2011 / 2012 dropped down to $1.25 \%$ in $2012 / 2013$, implying a decreaseof $2.64 \%$.

Table 8. School transition rate from SD/MI to SMP+MTs 2012/2013-2013/2014

\begin{tabular}{|c|c|c|c|c|c|c|c|}
\hline \multirow{2}{*}{ No } & \multirow{2}{*}{ District } & \multicolumn{3}{|c|}{$2012 / 2013$} & \multicolumn{3}{|c|}{$2013 / 2014$} \\
\hline & & Male & Female & $\mathrm{M}+\mathrm{F}$ & Male & Female & $\mathrm{M}+\mathrm{F}$ \\
\hline 1 & North Magelang & 167.13 & 167.81 & 167.47 & 384.62 & 357.03 & 370.83 \\
\hline 2 & Central Magelang & 55.48 & 63.17 & 59.33 & 196.81 & 222.84 & 209.83 \\
\hline 3 & South Magelang & 210.68 & 216.18 & 213.43 & 235.47 & 285.06 & 255.40 \\
\hline & Magelang City & & & 146.76 & & & 278.68 \\
\hline
\end{tabular}

Source : Education office of Magelang (2014).

From the above data, it can be inferred that, in Magelang, the number of students who continued their studies from SD/MI to MP/MTs was $146.76 \%$ in $2012 / 2013$ and $278.68 \%$ in $2013 / 2014$, implying that there was definitely an increase. From the above data, it is clear that the highest number of students continuing their studies was from North Magelang district, namely 370.83, followed by South Magelang district Meanwhile, Central Magelang District was ranked at the third with a total number of 209.83 .

Table 9. School transition rate from SMP/MTs to SMA 2011/2012-2012/2013

\begin{tabular}{llcccccc}
\hline \multirow{2}{*}{ No } & \multirow{2}{*}{ District } & \multicolumn{3}{c}{$2012 / 2013$} & \multicolumn{3}{c}{$2013 / 2014$} \\
\cline { 3 - 7 } & & Male & Female & $\mathrm{M}+\mathrm{F}$ & Male & Female & $\mathrm{M}+\mathrm{F}$ \\
\hline 1 & North Magelang & 50.00 & 69.00 & 59.00 & 103.45 & 111.72 & 107.59 \\
2 & Central Magelang & 30.00 & 46.00 & 38.00 & 107.72 & 141.88 & 124.80 \\
3 & South Magelang & 106.00 & 143.00 & 125.00 & 365.73 & 365.79 & 365.76 \\
& Magelang City & 62.00 & 86.00 & 74.00 & 192.3 & 206.46 & 199.38 \\
\hline
\end{tabular}

Source : BPS, Magelang City (2013).

Based on the above table, it can be seen that the number of the students continuing to Senior High School (SMA) in Magelang was 62.00 males and 86.00 females in 2012/2013. When compared with the year 2013/2014, the transition rate to senior secondary school (SMA/SMK) increased very highly, for both males and females, namely 192.3 and 206.46. This is due to the fact that the 12-year compulsory education had caused a high rate of students continuing their studies to SMA/SMK, even more than the schools' capacities.

Table 10. Rate of school stops at grade 5 of SD 2012/2013-2013/2014

\begin{tabular}{llcccc}
\hline \multirow{2}{*}{ No } & District & \multicolumn{4}{c}{ Year } \\
\cline { 3 - 6 } & & $2012 / 2013$ & $2013 / 2014$ \\
\cline { 3 - 6 } & & $\mathrm{M}$ & $\mathrm{F}$ & $\mathrm{M}$ & $\mathrm{F}$ \\
\hline 1 & North Magelang & 394 & 386 & 343 & 363 \\
2 & Central Magelang & 560 & 532 & 419 & 478 \\
3 & South Magelang & 393 & 353 & 385 & 350 \\
\hline & Magelang City & 1347 & 1271 & 1147 & 1191 \\
\hline
\end{tabular}

Source: Magelang Education Profile.

From the above data it can be seen that, in Magelang, the number of students who stopped studying at Grade 5 
was 1347 males and 1271 females in 2012/2013. When compared with the year 2013/2014 which showed figures of 1147 males and 1191 females, there was a decrease in children who stopped studying at grade 5 of SD.

Table 11. Total of education package A \& B Takers Magelang City in 2012/2013-2013/2014

\begin{tabular}{llcccc}
\hline \multirow{2}{*}{ No } & \multirow{2}{*}{ District } & \multicolumn{2}{c}{$2012 / 2013$} & \multicolumn{2}{c}{$2013 / 2014$} \\
\cline { 3 - 6 } & & Package A & Package B & Package A & Package B \\
\hline 1 & North Magelang & 26 & 134 & 31 & 149 \\
2 & Central Magelang & 28 & 20 & 30 & 30 \\
3 & South Magelang & 45 & 115 & 43 & 107 \\
\hline & Magelang City & 109 & 269 & 104 & 286 \\
\hline
\end{tabular}

Source: Magelang Education Profile.

The above data indicate that the number of people learning in Package-A Program in 2012/2013 in Magelang was 109 , while in 2013/2014 it was104, implying a decreaseof 5 per cent. Meanwhile, Package B in the year 2012/2013 showed that there were 269 students, whereas in the year 2013/2014, there were 286, implying an increase of 17 per cent. This indicates that the Program of Package B had been already publicly known.

Table 12. SD and SMP teachers with undergraduate degrees (S1/D4)2012/2013-2013/2014-Magelang City

\begin{tabular}{llllll}
\hline \multirow{2}{*}{ No } & \multirow{2}{*}{ District } & \multicolumn{2}{l}{$2012 / 2013(\%)$} & \multicolumn{2}{l}{$2013 / 2014(\%)$} \\
\cline { 3 - 6 } & & SD (S1/D4) & SMP (S1/D4) & SD (S1/D4) & SMP (S1/D4) \\
\hline 1 & North Magelang & 175 & 243 & 252 & 296 \\
2 & Central Magelang & 242 & 213 & 248 & 240 \\
3 & South Magelang & 147 & 152 & 186 & 184 \\
\hline & Kota Magelang & 564 & 608 & 686 & 720 \\
\hline
\end{tabular}

Source: Profil Pendidikan Kota Magelang.

Elementary school (SD) teachers with the qualification of S1/D4 (undergraduate degrees) in Magelang were 564 in 2012/2013 and 686 in 2013/2014. This indicates that there was an increase by 122 . On the other hand, junior high school (SMP) with the qualification of S1/D4 was of 608 in 2012/2013 and 720 in 2013/2014, implying an increase of 112 .

Table 13. Ratio of teachers to students in SD and SMP 2012/2013-2013/2014-MagelangCity

\begin{tabular}{llcccc}
\hline \multirow{2}{*}{ No } & \multirow{2}{*}{ District } & \multicolumn{3}{c}{ RATIO OF TEACHERS TO STUDENTS } \\
\cline { 3 - 6 } & & \multicolumn{2}{c}{$2012 / 2013$} & \multicolumn{2}{c}{$2013 / 2014$} \\
\hline \multirow{nyyyyy}{*}{2} & North Magelang & 16 & SMP & SD & SMP \\
2 & Central Magelang & 17 & 15 & 3.97 & 13.46 \\
3 & South Magelang & 16,5 & 14 & 3.83 & 15.52 \\
& Kota Magelang & 16,5 & 15 & 4.13 & 12.4 \\
\hline
\end{tabular}

Source: Educational Profile of Magelang City.

From the above data, it can be clearly understood that the ratio of teachers to elementary (SD) students in Magelang in 2012/2013 was 16.5 and in 2013/2014 it became better (4.13). For the teacher to student ratio of SMP in Magelang in 2012/2013 was 15 and became better in 2013/2014 (13.8). This suggests that Magelang, for 
Teachers to Students Ratio, had already met the minimum standard, namely1: 32.2 .

\subsection{Discussion on SWOT Perspectives}

The results presented in 3.2 can be discussed in terms of SWOT (Strengths, Weaknesses, Opportunities and Threats) by presenting both internal and external analyses. Described as Strengths are among others (1) The Local Authority's commitment in and the Regional House Members' support to Basic Education is considerably high. (2) Both urban and rural families are very positively supporting. (3) Block grants are available for basic education, especially Package A+B, (4) Good cooperation between Educational Ministry and NGO's in support of the basic educational program implementation. Meanwhile, the Weaknesses include (1) Limited infrastructure, with some naturalized buildings and outdated teaching media, (2) Data and information have not been well organized, resulting in inconsistent data presentation between planning and budgeting (3) Regional Autonomy has caused slow and ineffective development of non-formal and informal education, resulting in shaky implementation of basic education.

Externally, basic education is faced with both opportunities and threats. The opportunities include full supports from Ministries of education and religion with respect to sustainability of basic education through (1) rehabilitation of educational facilities for SD/SMP throughout Indonesia. (2) Operational Grants for Schools, aimed at eliminating the basic cost of education. (3) Free textbooks available for students, (4) Dissemination of evaluation results for SD/SMP, and (5) Innovative programs for dropout students and those who never go to school. Furthermore, the challenges ahead include (1) The important of equal distribution of facilities, (2) concrete budgeting by the school committee, and (3) Making the best use of operational grants.

In business terms, it is important to create strategies that can convert Weaknesses into Strengths and Threats into Opportunities. This is the basic rationale for developing a model of acceleration, as presented below:

\subsection{Model of Acceleration}

Below is the proposed model of acceleration that can be applied in basic education mastery learning. The model was tested in a limited scope within Megelang municipality to find out possible discrepancies for further revision by focused group discussion (FGD) to generate the final product. The main target is to achieve MDGs in 2015.

\section{A Model of Basic Education Mastery Learning Acceleration (Community Based)}

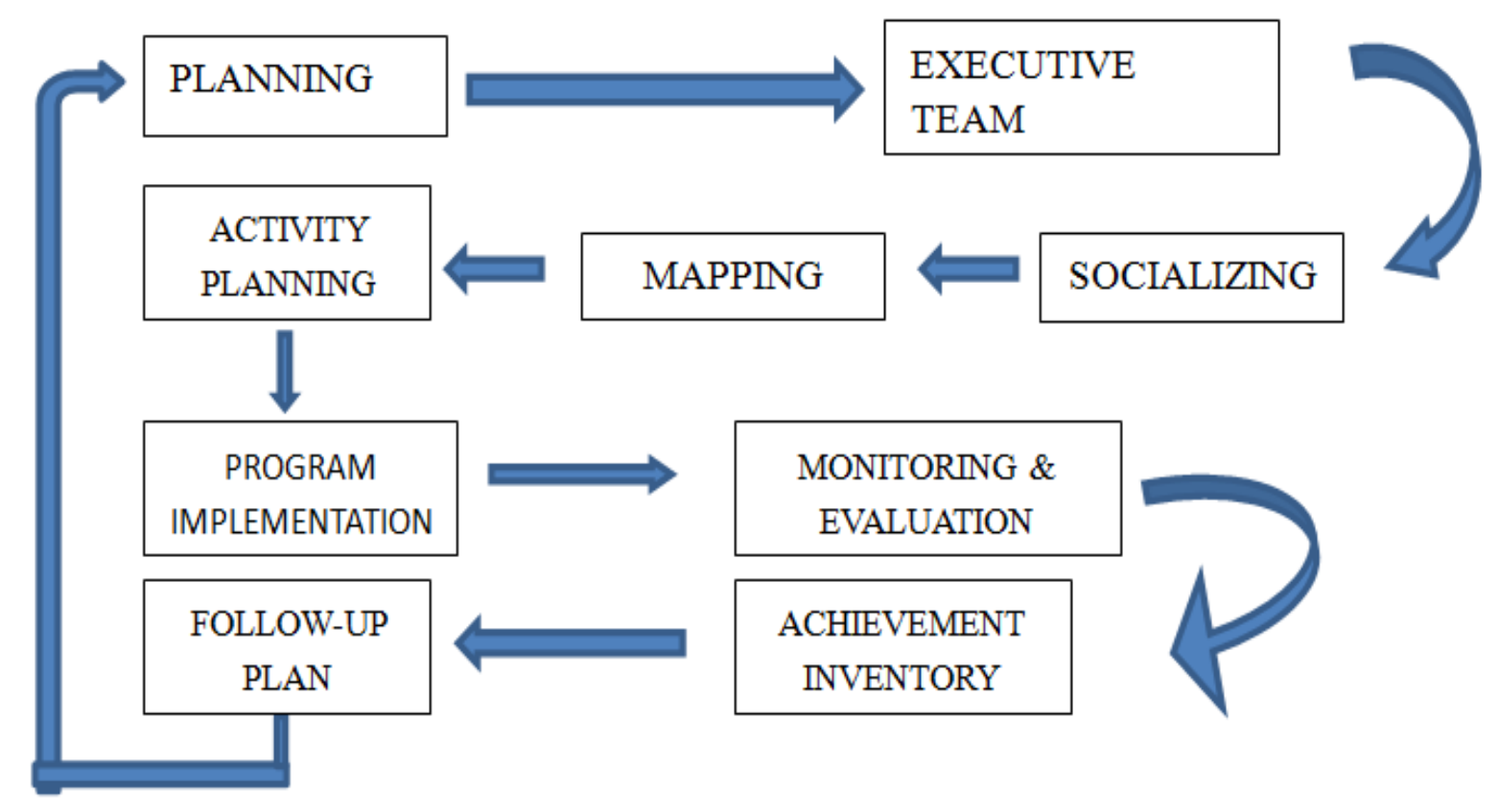

Exhibit 1. A Model of Basic Education Mastery Learning Acceleration 
It is clear from Exhibit 1 that, in order to accelerate the mastery learning of basic education, a down-to-earth and procedural model has been designed with the following mechanism of implementation.

It starts with planning in which it consists of (1) name of activities, (2) time and place of activity, budget, etc. Upon completion of the proposed plan, an executive team can be formed. The team consists of city, district and village-based coordinators whose tasks are to design the project of accelerating basic education mastery learning within each level of coordination.

The next step is to socialize the program through social media, seminars, and meetings in order for the parties concerned to know the working mechanism of the project. Then, the team continues by mapping. This includes taking inventories of data, namely (1) school-age children but not going to school, (2) illiterate citizens, (3) total number of children that must go to school, (4) total number of students outside and within the schooling age, (5) total number of student taking Education Package A \& B, (6) rates of dropouts, repeaters, up-movers, (7) teachers and tutors available, (8) infrastructure available.

Based on the mapping, the team designs the activities, including (1) prioritizing acceleration of basic education mastery learning in those areas absolutely of high and pressing needs, (2) selecting suitable patterns according to the local interests of the region (3) empowering every possible potency of the people, (4) adapting the characteristics of the region, (5) making use of paternalistic nature of the people, (6) making relationship with related parties, (7) providing necessary educational instruments and media, (8) monitoring and evaluation.

The process of program implementation includes activities, such as (1) submission of proposal based on provincial budget, (2) evaluation and acceptance of the proposal, (3) release, use, and report of funds, and (4) project execution.

On execution of the programs, monitoring (supervision) and evaluation have to be properly conducted to guarantee program implementation as a whole. Any achievement of performance has to be well documented as a feedback for follow-up activities.

\section{Conclusion and Recommendations}

Much has been discussed on the implementation of compulsory basic education program at Magelang, Central Java, Indonesia, in compliance with MDGs that should be achieved in 2015. The local authority of Magelang has been highly committed to this project in accordance with the Government's policy as expressed in the strategic plan of Education Ministry. In 2014, a team of program coordinators executed 23 programs. However, the programs were approached by employing the top-down system of management, resulting in a low participation of the society members - potential people as the subjects of the programs were not optimally involved.

It is therefore recommended (1) that the Local Authority of Magelang keep up the good work and maintain sustainability of the commitment to quality education, (2) that people's participation, to accelerate the completion of compulsory basic education, be more activated and optimized in planning, executing, monitoring and evaluating the programs, (3) that optimizing people's participation in education be supported by all the parties concerned, including the stakeholders.

\section{Acknowledgements}

The researchers' sincere thanks shall go to Magelang Board of Education and Tidar University for the research grant. As well, all research participants whose names cannot be mentioned one by one are highly appreciated for all the time and efforts dedicated to the completion of this study.

\section{References}

Borg, W. R., \& Gall, M. D. (2007). Educational Research: An Introduction. New York: Longman

Dinas Pendidikan Provinsi Kalimantan Selatan. (2014). Panduan Workshop Penyusunan Millenium Development Goals (MDGs). Retrieved July 10, 2014, from http://www.disdik.kal-selprov.go.id

Kementerian Perencanaan Pembangunan Nasional/Bapenas. (2010). Ringkasan Peta Jalan Percepatan Pencapaian Tujuan Pembangunan Milenium di Indonesia. Jakarta: Bapenas.

Kementerian Perencanaan Pembangunan Nasional/Bapenas. (2013). Laporan Perencanaan Pencapaian Tujuan Pembangunan Milenium di Indonesia. Jakarta: Bapenas.

Kompas. (2013). Hasil Uji Kompetensi Guru (UKG). Read/2013/01/23/155485/PGRI.

Peraturan Pemerintah Nomor. (2005). Standar Nasional Pendidikan. Jakarta:Depdiknas.

Sugiono. (2009). Metode Penelitian Pendidikan: Pendekatan Kuantitatif, Kualitatif, dan R\&D. Bandung: 
Penerbit Alfa Beta.

Tim Monitoring dan Evaluasi Pendidikan Untuk Semua (PUS) Kota Magelang. (2014). Laporan Pelaksanaan Pendidikan Untuk Semua (PUS) Kota Magelang 2014.

Undang-Undang Republik Indonesia. (2003). Sistem Pendidikan Nasional. Jakarta: Depdiknas.

\section{Copyrights}

Copyright for this article is retained by the author(s), with first publication rights granted to the journal.

This is an open-access article distributed under the terms and conditions of the Creative Commons Attribution license (http://creativecommons.org/licenses/by/3.0/). 